\title{
FORMATION OF THE COMMUNICATIVE COMPONENT OF PROFESSIONAL IDENTITY OF FUTURE SPECIALISTS IN PHYSICAL THERAPY, ERGOTHERAPY
}

The purpose of the article is to investigate the formation of the communicative component of professional identity of future specialists in physical therapy, ergotherapy. The communicative component of professional identity contributes to the development of the professional image of "I" of the future specialist through the formation of a community of cognitive and practical activities, relationships and communication in the professional team, socialization of the individual - through the development of skills to establish and maintain effective communication with other people. The communicative component implies the presence of a set of professional and personal qualities, skills, skills, which are the basis of a specialist's readiness for pedagogical communication with representatives of various social and age groups, direct him to search and make effective decisions in situations of interaction with students, parents, colleagues. to listen, understand and be understood by other subjects of communication. For the purpose of scientific substantiation and experimental verification of the complex of psychological and pedagogical conditions that contribute to the development of the communicative component of professional identity in the future specialists in physical therapy, ergotherapy, the authors organized a study in which 310 students participated in 1-2 courses of the Department of Physical Therapy. It is established that the values of development of the communicative component of professional identity of future specialists in physical therapy are predominantly specialized; the ability to describe their own and others' feelings and experiences by reducing the level of alexithymia; in developing communication skills. This is especially important at the stage of formation and development of socio-professional activity, since the future professional activity of physical therapists and ergotherapists is connected with communication, and the orientation towards acceptance of a partner for communication is a necessary motivational trend in the profession.

Key worlds: professional identity, future specialists, communicative component, education, vocational training, vocational education pedagogy, physical therapy, ergotherapy.

\section{(статтю подано мовою орихіналу)}

At the present stage of development of society, an important task of education is the development of students' communicative tolerance in the sociocultural environment. This is of great importance for their professional and personal development. The relevance of the study is due to the need of society for specialists in physical therapy and ergotherapy - responsible, with self-esteem, tolerantly interacting with people from different social groups, different ages, different ethnic backgrounds.

One of the fundamental tasks of the professional training of future specialists in physical therapy, ergotherapy is to form in the future physical therapists and ergotherapists a view of their future professional activity as a single interdependent whole, the ability to see and understand the problems that arise and ways.

Future physical therapists or ergotherapists should be carriers of human and cultural values and strive for selfimprovement. Their professional competence is formed in the process of teaching not only special, but also general education disciplines. Researchers believe that the integration of general education with the professional provides motivation for their study, resulting in the formation of professional identity.

Professional identity is associated with the processes of professional self-determination, personalization and selforganization, awareness of oneself as a representative of a particular profession and professional community, characterized by a degree of identification-differentiation of oneself with business and others, manifested in cognitive-emotional-behavioral self.

Professional identity in its concept is closely interrelated with concepts such as professional development, professionalism, professional self-esteem, professional self-determination, and is one of the main criteria for becoming a professional in a competitive environment. In other words, in order to exist in dynamic socio-economic conditions, a modern professional must be capable of continuous development and analysis, an awareness of his place in the professional environment. The formation of a professional identity is the most important task that a professional faces in the period of his / her professional development.

Theoretical analysis of different concepts and approaches to the study of this concept allows us to define the concept of "identity" as a multidimensional and integrative psychological phenomenon, which is the result of an active process of self-representation associated with the continuous process of development of human personality throughout his life. At the same time, it should be noted that this process is not a linear process and can have the opposite effect, returning to a lower level. In doing so, a person makes a series of interrelated choices, taking on their personal goals, values, beliefs.

A person's professional choice is a lengthy process that involves a series of interrelated decisions and stages, spanning over ten years. The process of choosing a profession is irreversible, which ends in a compromise between external and internal factors. By external factors we mean the prestige of the profession, the situation in the labor market, internal - individual psychological characteristics of the individual [4].

The purpose of the article is to investigate the formation of the communicative component of professional identity of future specialists in physical therapy, ergotherapy. 
The communicative component of professional identity contributes to the development of the professional image "I" of the future specialist through the formation of a community of cognitive and practical activities, relationships and communication in the professional team, socialization of the individual - through the development of skills and ability to establish and maintain effective communication with other people $[1,2,6]$. The communicative component implies the presence of a set of professional and personal qualities, skills, skills, which are the basis of a specialist's readiness for pedagogical communication with representatives of various social and age groups, direct him to search and make effective decisions in situations of interaction with students, parents, colleagues. to listen, understand and be understood by other subjects of communication.

The communication activity of a specialist in physical rehabilitation is a constant component of his professional activity, since the specifics of his work as a teacher implies that he is both a source of information and the organizer of the rehabilitation process, relationships and communication in the team. There is no doubt that the level of professional identity of a future physical rehabilitation specialist depends on the level of development of his or her communication skills.

When considering the communicative component as a capacity for therapeutic effects, its content can be cited as an opportunity to establish effective relationships between the rehabilitation specialist and the patient according to his condition and diagnosis. In general, none of the functions of a specialist in physical rehabilitation can be realized beyond the limits of his interaction and communication with patients, that is, in the professional activity of communication is a universal category $[3,6,10]$.

We consider it appropriate to single out the following components in the structure of the communicative component of the professional identity of the cognitive: cognitive (awareness and internalization of the ideas of tolerant communication); instrumental (mastery of a set of communicative skills); conative (initiative, activity and social responsibility, dialogue dialogue); emotional (the attitude of the individual to the process and the results of tolerant communication, satisfaction with the system of interpersonal relationships) [1, 7, 8]. This structure of communicative tolerance reflects the unity of the substantive and procedural aspects of the development of future specialists in physical therapy, ergotherapy of communicative tolerance in the social and cultural environment of a higher educational institution [3,9].

Future specialists in physical therapy and ergotherapy, in our opinion, are in the system of social relations, which is aimed at the formation of social and professional activity during the period of education. The development of communicative tolerance can be carried out both within the framework of teaching the disciplines of the humanitarian cycle in the formation of communicative skills, and in educational educational extracurricular activities.

For the purpose of scientific substantiation and experimental verification of the complex of psychological and pedagogical conditions that contribute to the development of communicative tolerance among future specialists in physical therapy, ergotherapy, the authors in 2015 - 2019. A study was organized in which 310 students of 1-2 courses of the Department of Physical Therapy took part.

The main research methods were: observation, diagnostic, linear experiment, conversation, questioning; popular diagnostic techniques - V.V. Boiko diagnosis of the level of empathic abilities; Ladanov, V.A. Urazaev diagnosis of motivational orientations in interpersonal communications; T. Lyry methodology "Study of communicative characterological trends"; V.V. Boiko diagnosis of communicative tolerance; N.P. Fetyskyn, V.V. Kozlov, H.M. Manuilov Diagnostics of communicative social competence.

As a result of the study, it was revealed that the average (54\%) and underestimated level of empathy development prevails among students (33\%). And only $4 \%$ of students are characterized by a high level of development of empathy and $9 \%$ - a low level. In general, students are focused on understanding a communication partner (43\% of students have a high level of orientation on understanding a partner, $37 \%$ of students have an average level of this orientation). In the process of interpersonal interaction, subjects try to accept a communication partner as he is $(31 \%$ are characterized by showing respect for the personality of the communication partner, accepting his personality and interests). A compromise orientation has an average level of severity in $68 \%$ of students. Subjects tend to exercise restraint in conflict situations, to take into account the point of view of the interlocutor and his interests. $53 \%$ of students have an average level of expression of the general harmony of motivational tendencies in interpersonal relationships. 56\% of students are characterized by an average level of development of communicative tolerance.

In general, the orientation toward the adoption of a communication partner is a necessary motivational tendency in the profession of a physical therapist. In his activity, a physical therapist and occupational therapist should strive to consider him as a person and individuality and accept him as he is, with its advantages and disadvantages.

Experimental experimental work on the development of communicative tolerance of future specialists in physical therapy, ergotherapy is aimed at implementing the system of psychological and pedagogical conditions that we have identified and includes:

- enrichment of students' knowledge on this issue at lectures, seminars, extracurricular independent work in the following disciplines: philosophy, pedagogy, professional mastership, psychology, using various technologies: interactive forms of work, group work, business game, trainings, interactive communication at the lecture, problematic discussions;

- development of students' communicative tolerance in cognitive activity through participation in various events: festivals, conferences, round tables, lectures, curatorial hours; the assimilation of moral standards and standards 
of behavior through the inclusion of students in joint social activities (volunteer activities, participation in student social organizations).

Taking into account the content of communicative tolerance in the context of ideas of personality-oriented education, the main means of creating pedagogical situations aimed at developing communicative tolerance of future specialists in physical therapy, ergotherapy, are dialogue - as a way of mastering personal experience, business and role-playing game - as a means of modeling the socio-cultural environment. The developed typology of the "dialogue" was applied and games and trainings were designed: role-playing, associative, communicative, active, the joint use of which created the conditions for more effective achievement of the goals at each stage. The work on the development of communicative tolerance involves two areas: the first is the mastery of the theoretical and practical side of communicative tolerance under the guidance of a teacher; the second is the independent activity of students in extracurricular activities.

At the control stage of the experiment, the effectiveness of the practice-oriented work was assessed by the level criterion of the dynamics of the development of communicative tolerance. The study of the characteristics of the emotional sphere of students confirmed our assumption that they need to develop communicative tolerance, since many of them have a fairly high level of alexithymia, which is manifested in the difficulty in verbalizing emotional states. However, during the experiment, positive dynamics and a tendency to move to a higher level of development of communicative tolerance and empathic communication were revealed. Indicators of a high level of empathy increased from 4 to $9 \%$, average - from 54 to $57 \%$, and underestimated decreased from 33 to $29 \%$ and low - from 9 to 5\%; the propensity for communicative tolerance increased from 56 to $61 \%$.

So, the results of an experimental study confirm the feasibility of choosing a set of psychological and pedagogical conditions that ensure the development of communicative tolerance among future specialists in physical therapy and ergotherapy in a higher educational institution.

Factors contributing to the development of communicative tolerance include:

- the formation of the spiritual culture of student society: the students' joint experience of a sense of belonging to the student subculture, belonging to an educational institution, familiarization with high life goals and values;

- the functional inclusion of teachers in joint activities with students, in accordance with the organizational order, rules and traditions adopted at the university;

- the saturation of the educational process with group and individual actions of various kinds: events, sports, contests, art.

Therefore, the main importance of the development of the communicative component of the professional identity of future specialists in physical therapy, egrotherapy is to increase the level of empathy; the ability to describe their own and other people's feelings and experiences through a decrease in the level of alexithymia; in the development of communication skills. This is especially important at the stage of formation and development of social and professional activity, since the future professional activities of physical therapists and occupational therapists are associated with communication, and orientation toward the adoption of a communication partner is a necessary motivational tendency in the profession.

Bibliography:

1. Балданова Е. А. Развитие коммуникативной толерантности студентов технического вуза средствами иностранного языка : дис. ... канд. пед. наук. Улан-Удэ, 2011. 219 с.

2. Гребенец Е. С. Формирование коммуникативной толерантности у старшеклассников во внеучебной деятельности : дис. ... канд. пед. наук. Москва, 2013. 173 с.

3. Громкова М. Т. Психология и педагогика профессиональной деятельности : учебное пособие для вузов. Москва : Юнити-Дана, 2003. 415 с.

4. Дмітрієва Н. С., Копочинська Ю. В. Формування професійної ідентичності майбутніх фахівців із фізичної терапії як фактор підвищення їх конкурентоспроможності. Збірник наукових праиь Херсонського державного університету. Педагогічні науки. 2019. Вип. 79(3). С. 105-110. DOI : 10.32999/ksu2413-1865/2019-87-19.

5. Каган М. С. Мир общения: проблемы межсубъектных отношений. Москва : Политиздат, 1998. 315 с.

6. Калач Е. А. Учебно-профессиональное взаимодействие как фактор успешного развития коммуникативной толерантности студентов специальности «связи с общественностью» : дис. ... канд. пед. наук. Ижевск, 2006. 223 с.

7. Климов Е. А. Индивидуальный стиль деятельности в зависимости от типологических свойств нервной системы. Казань, 1969. $237 \mathrm{c}$.

8. Скрябина А. Б. Педагогические условия формирования коммуникативной толерантности у старшеклассников : дис. ... канд. пед. наук. Кострома, 2000. 209 с.

9. Толстикова С. Н. Развитие коммуникативной толерантности у будущих социальных педагогов системы образования : дис. ... канд. психол. наук. Калуга, 2002. 176 с.

10. Яцевич Л. П. Формирование коммуникативной толерантности у будущих специалистов социальной работы : дис. ... канд. пед. наук. Чита, 2010. 193 с.

\section{References:}

1. Baldanova E. A. (2011). Razvytye kommunykatyvnoi tolerantnosty studentov tekhnycheskoho vuza sredstvamy ynostrannoho yazyka : dys. kand. ped. nauk [The development of communicative tolerance of students of a technical university by means of a foreign language: dis. Cand. ped Sciences]. Ulan-Ude, p. 219. 
2. Hrebenets, E. S. (2013). Formyrovanye kommunykatyvnoi tolerantnosty u starsheklassnykov vo vneuchebnoi deiatelnosty : dys. kand. ped. nauk [Formation of communicative tolerance in high school students in extracurricular activities: dis. Cand. ped Sciences]. Moscow, p. 173.

3. Hromkova M. T. (2003). Psykholohyia y pedahohyka professyonalnoi deiatelnosty : Uchebnoe posobye dlia vuzov [Psychology and pedagogy of professional activity: Textbook for universities]. Moscow: Yunyty-Dana.

4. Dmitriieva N. S., Kopochynska Yu. V. (2019). Formuvannia profesiinoi identychnosti maibutnikh fakhivtsiv z fizychnoi terapii yak faktor pidvyshchennia yikh konkurentospromozhnosti [Formation of the Professional Identity of Future Physical Therapy Specialists as a Factor for Increasing their Competitiveness]. Zbirnyk naukovykh prats [Khersonskoho derzhavnoho universytetu]. Pedahohichni nauky [Collection of Scientific Papers [Kherson State University]. Pedagogical Sciences], 79(3), p. 105-110. DOI : 10.32999/ksu2413-1865/2019-87-19.

5. Kahan M. S. (1998) Myr obshchenyia: problemy mezhsubektnykh otnoshenyi. The world of communication: problems of intersubjective relations. Moscow: Polytyzdat, 1998. 315 p.

6. Kalach E. A. (2006). Uchebno-professyonalnoe vzaymodeistvye kak faktor uspeshnoho razvytyia kommunykatyvnoi tolerantnosty studentov spetsyalnosty «sviazy s obshchestvennostiu» : dys. kand. ped. nauk [Educational-professional interaction as a factor in the successful development of communicative tolerance of students of the specialty "public relations": dis. Cand. ped sciences]. Izhevsk, p. 223.

7. Klymov E. A. (1969). Yndyvydualnyi styl deiatelnosty v zavysymosty ot typolohycheskykh svoistv nervnoi systemy [Individual style of activity depending on the typological properties of the nervous system]. Kazan.

8. Skriabyna A. B. (2000). Pedahohycheskye uslovyia formyrovanyia kommunykatyvnoi tolerantnosty u starsheklassnykov : dys kand. ped. nauk [ Pedagogical conditions for the formation of communicative tolerance in high school students: dis. Cand. ped Sciences]. Kostroma, p. 209.

9. Tolstykova S. N. (2002). Razvytye kommunykatyvnoi tolerantnosty u budushchykh sotsyalnykh pedahohov systemy obrazovanyia : dys. kand. psykhol.nauk [The development of communicative tolerance in future social educators of the educational system: dis. Cand. Psychol.Science]. Kaluha, p. 76.

10. Yatsevych L. P. (2010). Formyrovanye kommunykatyvnoi tolerantnosty u budushchykh spetsyalystov sotsyalnoi raboty : dys. kand. ped. nauk [Formation of communicative tolerance among future specialists in social work: dis. Cand. ped sciences]. Chyta, p. 193.

Копочинська Ю. В. Формування комунікативного компонента професійної ідентичності майбутніх фахівців із фізичної терапії, ерготерапії

Метою статті є дослідження формування комунікативного компонента професійної ідентичності майбутніх фахівців із фізичної терапї, ерготерапї. Комунікативний компонент професійної ідентичності сприяє розвитку професійного образу «Я» майбутнього фахівия через формування спільності пізнавально-практичної діяльності, взаємовідносин та спілкування у професійному колективі, соиіалізації особистості за рахунок розвитку вмінь $і$ навичок установлення й підтримання ефективного спілкування з іншими людьми. Комунікативний компонент передбачає наявність сукупності професійно-особистісних якостей, умінь, навичок, які є основою готовності фахівия до педагогічного спілкування з представниками різноманітних соціальних та вікових груп, спрямовують його на пошук та прийняття ефективних рішень у ситуаиіях взаємодії з учнями, батьками, колегами, розвивають уміння слухати, розуміти й бути зрозумілим для інших суб' єктів комунікації. 3 метою наукового обтрунтування та експериментальної перевірки комплексу психологічних і педагогічних умов, щзо сприяють розвитку комунікативного компонента професійноі ідентичності у майбутніх фахівців із фізичної терапії, ерготерапії, авторами проведено дослідження, в якому взяло участь 310 студентів I-II курсів кафедри фізичної терапії. Установлено, щцо переважно розвиток комунікативного компонента професійної ідентичності майбутніх фахівців із фізичної терапії, егротерапіі полягає у підвищенні рівня емпатії; здатності описати власні $і$ чужі почуття $і$ переживання через зниження рівня алекситимї̈; у розвитку комунікативних навичок. Це особливо важливо на етапі становлення і розвитку соціально-професійної активності, оскільки майбутня професійна діяльність фізичних терапевтів і ерготерапевтів пов'язана зі спілкуванням і орієнтація на прийняття партнера по спілкуванню є необхідною мотиваційною тенденцією у професії.

Ключові слова: професійна ідентичність, майбутні фахівиі, комунікативний компонент, освіта, професійна підготовка, педагогіка професійної освіти, фізична терапія, ерготерапія. 